\title{
"MY DEAR COMRADE FREDERICKUS": WALT WHITMAN AND FRED GRAY
}

\author{
Stephanie M. Blalock
}

IN A MAY 1, 1863, letter to Walt Whitman, John Frederick Schiller Gray, or "Fred Gray" as the poet affectionately dubbed him, recorded his nostalgia for his friendships with Whitman and other regulars at Pfaff's beer cellar in New York during the summer of 1862. Gray admitted that the escalation of the Civil War and the beginning of his own appointment as an aide-de-camp, transcribing orders and sending correspondence, had effected a profound change, transforming the previous summer's "good old times" into fond but faraway memories and forcing him to lead a different life with Union Generals who kept him "constantly on the 'go."' He confided to Whitman that, at times, fulfilling the "detestable clerical responsibilities" of his position meant he was no longer as happy as he had been before his social circle of young men-about-town in New York was "entirely broken up" by enlistments and military duties. Gray even went so far as to insist, "I'm damned if I wouldn't have given up all my hopes in the future" to go back to beer dives, "disreputable "cakes and ale," and carefree evenings with Whitman (Shively, 148).

Caught between his need to care for the wounded soldiers in Washington, D. C., hospitals and a restless desire to return to his native New York, Whitman expressed a similar longing for Fred Gray's company in an October 8, 1863, letter to fellow Pfaffian Hugo Fritsch: "[M]y own comrade Fred, how I should like to see him \& have a good heart's time with him, \& a mild orgie." 2 The poet went on to explain that he wanted "to be within hand's reach" of both men so they could talk, drink, and carouse together (Corr, 1:158). He also asserted that his friendship with Gray as well as his affinity for Gray's associates ensured that their alliance would "remain a group of itself in the portrait-gallery of my heart . . . yet \& forever" (Corr, 1:159). Although Whitman does not name the group in this letter, Fritsch (his correspondent) and the other men he mentions here are members of what he refers to elsewhere as the "Fred Gray Association," a circle of New York comrades with whom he enjoyed "late wandering[s] [on] the east side of the City." 3 Ed Folsom and Ken Price describe the Association as "a loose confederation of young men who seemed anxious to explore the new possibilities of male- 
male affection."4 The group often met at Pfaff's, a basement beer cellar on Broadway and, less frequently, at other lager beer saloons throughout the city. According to The Vault at Pfaff's, Lehigh University's electronic archive, this Association of laughers and drinkers included Whitman, Gray, Hugo Fritsch, Nat Bloom, Charles Russell, Charles Kingsley, Charles Chauncey, and men Whitman records only as "Perkins" and "Raymond." While biographical information about most of these men has been scarce at best, it is certain that the Association counted among its members merchants, sportsmen, and a highly literate student John F. S. "Fred" Gray, for whom the group was named.

Despite Whitman's close ties to the Fred Gray Association and his admirable efforts to maintain the "lambent electricity" of these bonds through wartime correspondence, the poet lost contact with several of the Pfaffians - not excepting Fred Gray - in the years following the war (Corr, 1:158). As a result, little information about Fred Gray's past and fewer details about the fulfillment of his hopes for "the future" have emerged. In an effort to shed light on Gray's life and his friendship with Whitman, I offer the following biographical sketch in which I present Gray as a son, soldier, medical student, and father. In doing so, I hope to show that learning about Fred Gray, one of Whitman's favorite comrades, further illuminates the poet's place at Pfaff's beer cellar and reveals an important potential link between Whitman and the nearby Broadway medical community.

The Fred Gray Association was well on its way to becoming a wartime casualty by the Fall of 1862 when Gray said good-bye to Whitman and, at least temporarily, to his home state of New York as he began his stint in the Union Army. Although the war scattered the Association's members across the country and made it far less likely that the men would, as Whitman put it, "have our drinks \& things, $\&$ resume the chain $\&$ consolidate $\&$ achieve a night better . . . than ever," Gray wanted Whitman to remember him. ${ }^{6}$ On August 29, 1862, at "Raefelle's in $6^{\text {th }}$ st," Gray presented Whitman with a parting gifta treasured copy of Frederic Hedge's Prose Writers of Germany that Gray's father, Dr. John F. Gray, had given him on August 12, 1856, his sixteenth birthday. ${ }^{7}$ Certainly the book-an assemblage of representative extracts from Kant, Lavater, and Hegel, among others-was a meaningful expression of Dr. Gray's love for Fred and his interest in his son's literary and philosophical education. Likewise, it is tempting to speculate that this title was significant for Fred, Whitman, and their friendship. Since Fred Gray spent the 1860-1861 academic year in Germany studying at the University of Heidelberg, he undoubtedly shared the details of his experience with Whitman. ${ }^{8}$ It is also possible that the pair had discussed the book (or works by the writers included 
therein) during previous meetings. But regardless of whether Gray and Whitman had ever debated the merits of German literature over mugs of lager beer, Fred requested that Whitman "keep this book as a memento of him," and the poet documented this meeting as well as their future encounters by writing a note in it each time they were together. ${ }^{9}$ Honoring Gray's request to remember him, Whitman wrote a brief description of their last meeting before his comrade's departure: "Sept. 2, '62-Fred Gray (at Leotards) in $26^{\text {th }}$ street-evening-(he is to go to $=$ morrow to the army.)." $" 10$

Before Fred Gray left New York, he donned his military uniform and posed for a photograph in the office of Brassart, Johnson, and Williams, Photographers. August P. Brassart, a former associate of L. J. M. Daguerre (best known for his invention of the daguerreotype process of photography), helped establish this prospering studio, which was located at the corner of Broadway and Twenty-third Street, opposite the Fifth Avenue Hotel and not far from Pfaff's beer cellar. ${ }^{11}$ These photographers were charged with capturing a turning point in Gray's life and producing an image that marked his separation from his associates and the beginning of his military service. Fred Gray or a family member gave Whitman one of the resulting full-length card photographs of the young soldier, complete with Gray's name and the date, "Sept. $3^{\text {rd }}$ '62," inscribed on the front and the name and address of the photographers on the back. Whitman preserved the photograph by taping it "hinge fashion" into the copy of Hedge's Prose Writers of Germany that Gray had given him (Van Egmond, 46). He also pasted a second card photograph - this time a bust shot of Gray in his uniform-on the verso of the volume's first blank sheet. In doing so, Whitman ensured that Fred Gray would remain in the "portrait-gallery of [his] heart" as both a bar-room companion with whom the poet shared an unforgettable summer and a soldier who was only days away from confronting the horrors of the battlefield.

On September 6, 1862, John F. S. "Fred" Gray was officially enrolled in the Union Army at Washington, D.C. He was mustered into service as a second lieutenant in the Twentieth New York Infantry Volunteers to serve for two years before being detailed as an aide-decamp on the staff of Major-General William Farrar Smith. ${ }^{12}$ As an aide-de-camp, Gray assisted with tours of inspection and undertook numerous clerical responsibilities, including copying and sending military orders; or as Ted Genoways puts it, Gray was "serving with a pen rather than a rifle."13 Gray excelled in the performance of these duties, and Major-General Smith praised the young officer for serving "faithfully and gallantly" through the Battle of Antietam, fought on September 17, 1862, near Sharpsburg, Maryland. ${ }^{14}$ In the aftermath 
of Antietam, the bloodiest single-day battle in American history, Gray was granted a two-day leave, and he returned to New York to reunite with his associates. Eager to see his comrade and hear the latest war news, Whitman met Gray, likely for dinner and a round of drinks, as soon as he was back in the city: "I spent the evening with him, (at Pfaff's \&c) - He gave me a fearful account of the battle=field at $1 / 2$ past 9 the night following the engagement-He crossed it on duty." 15

In the weeks following Gray's "fearful" descriptions of the fighting and the incredible number of casualties at Antietam, Whitman appeared to grow even more concerned about Gray's safety and well-being. On October 1, 1862, soon after Fred's return to the field, Whitman noted in the Hedge volume that he visited Mrs. Gray (presumably Fred's mother) to ask if she had heard from her son. Mrs. Gray informed a seemingly worried Whitman that Fred was "well and satisfied with his position," and Whitman penciled those comforting words below his account of their post-Antietam meeting. In December 1862, only two months after this reassuring conversation with Mrs. Gray, Whitman too left the city, the Gray family, and the remaining members of the Fred Gray Association behind him. He headed south in search of his injured brother George, traveling first to Virginia and then taking up residence in Washington, D.C., where he worked in the Army Paymaster's office and continued to compose poignant letters to and about his dear "Freddy." 16 While Whitman visited scores of wounded soldiers in the hospitals of the nation's capitol, Gray climbed the ranks of the Union Army. In fact, Gray's service records, the aforementioned correspondence between Whitman and Gray, and Whitman's notes on their friendship provide much of the known information about Gray's activities during the war years. These documents are also the sources for most of the biographical data about Fred Gray that has been collected to date.

Drawing on the letters exchanged between Whitman and Fred Gray as well as Gray's New York obituaries, Edwin Haviland Miller's introduction and the editorial notes accompanying the first volume of Whitman's correspondence have long offered the most detailed biographical portrait of Fred Gray. ${ }^{17}$ As Miller explains, Gray rose first to the rank of captain and then to major before resigning from military service in 1865. Miller creates a timeline of Gray's postwar life, beginning with milestone events like his graduation from New York's College of Physicians and Surgeons in 1871 and his pursuit of a medical career in Paris, Nice, and Geneva, and ending with his death from Bright's Disease of the kidneys in St. Clair Springs, Michigan, in 1891 (Corr, 1:80-81n). He also identifies Gray's father as Dr. John F. Gray (1804-1882), an early convert to homeopathic medicine and a 
well-known New York physician (Corr, 1:84n). ${ }^{18}$ Whitman's visit with Fred Gray's mother and his insistence that Fred pay the poet's "best respects" to Dr. Gray suggest that Whitman was on familiar and friendly terms with both of Fred's parents. ${ }^{19}$ Emory Holloway even contends that Whitman and the rest of the Fred Gray Association occasionally held meetings at the Grays' home. ${ }^{20}$ Investigating the history of the Gray family - with whom Whitman continued to correspond (albeit indirectly) even after he left the city-reveals his comrade Fred Gray as both the son of a physician and an aspiring medical student in his own right. Furthermore, exploring Gray's heritage, his military service, and his postwar life stands to broaden scholars' understanding of the Fred Gray Association both as a significant group in Whitman's life and as part of the diverse clientele at Pfaff's beer cellar, which, as it turns out, included physicians and students from the local medical district. ${ }^{21}$

Marcius Denison Raymond's genealogical survey of the Gray family offers a detailed account of Fred Gray's parentage and descendants. Born John Frederick Schiller Gray on August 12, 1840, in New York, "Fred" Gray was one of only three children of Dr. John Franklin Gray and Elizabeth Hull-Gray to survive until adulthood. ${ }^{22}$ Fred's father, Dr. John F. Gray, graduated from the College of Physicians and Surgeons in 1826 and worked as an assistant surgeon in the Navy and at New York Hospital before opening a profitable practice on Carlton Street. ${ }^{23}$ In September 1826, he married Elizabeth Hull, the daughter of the prominent physician Dr. Amos G. Hull (Raymond, 20; 22). Soon after his marriage, Dr. Gray met and studied under Dr. Hans B. Gram, who, because of his English translation of Dr. Samuel Hahnemann's essay "Spirit of Homœpathy" from the original German, is credited with making the tenets of homeopathic medicine accessible to American physicians. ${ }^{24}$ As a result, Dr. Gray became one of the nation's earliest converts from the drastic cathartics and emetics of allopathic practice to the homeopathic system, which favored smaller doses of drugs and emphasized natural remedies. Dr. Gray facilitated the spread of homeopathy through his contributions to medical journals and by mentoring students at an office located at the corner of Hancock and Broadway. ${ }^{25}$ He divided his time, therefore, among his family, his career as a leading advocate of alternative medicine, and his role as a personal physician to the poet William Cullen Bryant (Raymond, 18-19). ${ }^{26}$ His son Fred seemed eager to follow in his footsteps; Fred, too, aspired to be a physician, seemingly setting his sights on what Raymond calls his father's "busy, active life in the great metropolis . . . [and his] professional career rarely equaled in the full measure of its success" (Raymond, 22).

In 1858, Fred Gray enrolled at Williams College in Massachusetts and began his education in science and medicine. He also joined the 
campus's chapter of Sigma Phi, the second oldest Greek social fraternity in the nation. ${ }^{27}$ After his sophomore year, Gray left Williams in order to study in Germany during the 1860-1861 academic year (CSP, 25253). While Gray attempted to concentrate on his coursework at the University of Heidelberg, the United States moved closer to Civil War as the southern states began to secede from the Union. By the end of Gray's junior year, in the spring of 1861, Confederate forces had fired on Fort Sumter in South Carolina, marking the start of the war. As a result, Gray decided to put his college career on hold; he left the University of Heidelberg without finishing his degree and returned to New York in order to enlist in the Union Army. He likely spent a portion of the following year (he did not enter the Army until September 3, 1862) in New York and Washington, D.C. (where he was enrolled). ${ }^{28}$ It is also likely that this is the period during which Gray frequented Pfaff's and met Whitman, the "old Boy" for whom he developed an "earnest affection." 29 As a medical student turned soldier, Gray's presence at Pfaff's suggests that this underground beer cellar was a place where Whitman could rendezvous safely not simply with Henry Clapp and the American Bohemians, but also with highly literate and upwardly mobile young men who had ties to the nearby New York Hospital, where Fred's father had once been employed and where Whitman encountered doctors and the injured stage drivers they treated. And while it is difficult to discern precisely when Whitman met Gray or whether the two knew each other prior to that memorable summer of 1862 , it is certain that by the following spring Gray had come to regard Whitman as a "very dear friend" whose "devotion to suffering man" made Gray "d----d proud" and prompted Mrs. Gray to laud the "good \& noble" Whitman (Shively, 148).

Although Gray longed to carouse with Whitman and looked forward to resuming the medical career he had postponed, he continued to impress Major-General Smith with his dedicated service. In a report on the operations of the Sixth Army Corps during the Battle of Fredericksburg, Smith praised Gray's "zeal and coolness" throughout the battle. ${ }^{30}$ Gray was soon promoted to captain, and on January 20, 1863, he was detailed as an aide-de-camp under Major-General John E. Wool - the oldest Union general in the Civil War and the Commander of the Department of the East. ${ }^{31}$ As a member of Wool's staff, Gray attended the General on his tours of inspection until March 1863, when Gray returned to New York and visited his (and Whitman's) comrades including Charles S. Kingsley, another potential member of the Fred Gray Association. In a March 21, 1863, letter to Whitman, Kingsley informed the poet that Fred had completed his tour "among the forts down east, including Portland, Portsmouth, Boston, Newport, New 
London . . . firing off all the guns to test their effectiveness" (Shively, 153) Gray, however, did not write a letter to Whitman until May 1, 1863, nearly two months after receiving one from the poet, in which Whitman confessed how much he missed his "darlings and gossips"-his dear friends from the Association (Corr, 1:82). In his response, Gray complained that assisting General Wool had prevented him from writing and expressing his affection for the poet "in a manner befitting . . . the memory of the 'good old times." In fact, even as Gray was composing this letter, he had just enough time to remind Whitman to continue their correspondence and record a fond "Good Bye old Boy" before he was "on the "go" again, following an order that charged him "to see about some d----d fortification" (Shively, 149).

Two weeks after writing to the poet, Fred Gray was relieved of his duties as a captain of Company A of the Twentieth New York Infantry so that he could begin a new appointment as an Assistant-Adjutant General of Volunteers. He accepted the position on May 13, 1863, in New York, but by the following May (if not before) he was on the move again. ${ }^{32}$ On May 7, 1864, Captain Gray was ordered to Cairo, Illinois, and instructed to report for duty to Major-General Edward R. S. Canby, who had helped to restore order in New York after the 1863 draft riots and had recently been named commander of the Military Division of West Mississippi. ${ }^{33}$ Upon receiving these instructions, Gray immediately wrote a brief note to Whitman: "Good bye! We are suddenly ordered away to the South-west. I will write you when we get settled!" (Shively 150). Gray's duties as Assistant-Adjutant General in the "South-west" remained primarily clerical; he transcribed orders for Canby and served at the siege and capture of Mobile Bay, Alabama (CSP, 252-253). In November 1864, Gray also volunteered for a special temporary assignment as an aide-de-camp on the staff of Brigadier-General John W. Davidson, Chief of Cavalry of the West Mississippi division, in New Orleans. ${ }^{34}$ Having completed the expedition with Davidson, Gray returned to Major-General Canby's staff in mid-December $1864 .{ }^{35} \mathrm{He}$ likely remained in or near New Orleans and Baton Rouge during the remainder of his military service, and for his faithful and meritorious performance of his duties in both Alabama and Louisiana, he was brevetted major in January $1865 .{ }^{36}$

On April 19, 1865, two weeks after Confederate General Robert E. Lee's surrender to General Ulysses S. Grant's Union forces at Appomattox, John F. S. Gray was relieved from army duty. ${ }^{37}$ He resigned from the military on May 5, 1865, only days after Confederate troops, under the command of General Joseph E. Johnston, surrendered to Union General William T. Sherman at Bennett Place in Durham, North Carolina. That same year, Gray married his first wife, Anna 
Howell (also recorded as "Laura") in Baton Rouge. ${ }^{38}$ With Fred Gray's time as a soldier having only just ended and the war itself drawing to a close, he and Anna headed north to New Jersey and then to New York, where Fred, Walt, and their associates had met at Pfaff's some three years earlier. Even though Gray returned to his home state and Whitman did visit New York during this period, it is doubtful that these two comrades were able to spend much time together. After all, during the first six years of their marriage, Fred and Anna Howell-Gray became the parents of five children. Fred and Anna's first child, Gerald Hull Gray - who would become a respected attorney - was born on September 20, 1866. Their second child, John F. Gray, arrived on December 18, 1867, followed by Edward (April 1869), Elizabeth Williams (July 18, 1870), and Mary (September 1871) (Raymond, 22). In addition to starting a family, Fred Gray resumed the study of medicine and once more set his sights on becoming a physician, like his father. Gray graduated on March 17, 1871, thereby completing the medical degree he had long desired, from his father's alma mater, the College of Physicians and Surgeons. ${ }^{39}$

After his graduation, Dr. John F.S. "Fred" Gray and his family continued to reside in New York, where Gray practiced medicine with his father. Then, in January 1873, Gray's one-year-old daughter, Mary, died. Later that same year, on December 9, 1873, Gray's wife, Anna "Laura" Howell, passed away, and suddenly, Gray found himself a widower caring for four children under the age of ten (Raymond, 22). In October 1877, Gray lost his youngest son Edward, who was only eight years old at the time of his death. During these difficult years of tremendous personal and familial loss, Gray sent his eldest sons, Gerald and John, to begin their education at St. John's School in Sing Sing, New York, and later, to prepare for college at the Roxbury Latin School in Roxbury, Massachusetts. ${ }^{40}$ Having lost his wife and at least two of his children, and (presumably) having placed his remaining sons in reputable academic institutions and/or in the care of his relatives, Dr. Gray went abroad, where he lived and worked in several European cities, including Geneva, Paris, and Nice. ${ }^{41}$ Dr. Gray's health had been compromised since the war and, at this time, his symptoms were undoubtedly exacerbated by stress and grief; however, in the mild, Mediterranean climate of Southern France, he managed to continue the medical education and practice he had begun in New York. He earned a Bachelor of Science from the Sorbonne in Paris and, on November 19, 1881, he received the Faculty of Medicine (M.D. First Class) of Montpellier, France. ${ }^{42}$

The following year, Dr. Gray spent a week (September 4 - September 9, 1882) at the Fourth International Congress of Hygiene in Geneva, Switzerland. The Congress, conducted in its official language 
of French, allowed science and medical professionals from around the world to gather for the purpose of discussing issues ranging from the disposal of sewage to the spread of viruses. ${ }^{43}$ The highlight of the Fourth Congress was a "great speech" prepared by M. Louis Pasteur on "the attenuation of the virus," including the "microbe of the saliva in hydrophobia [rabies]" that he "described for the first time before the Geneva Congress," thereby sharing the findings that would soon allow him to produce a vaccine for rabies. ${ }^{44}$ It is certainly possible that Dr. Gray attended Pasteur's talk, and Gray's presence at the Congress as well as his work at the Sorbonne and Montpellier reveal the realization of his hopes for achieving a successful medical career both at home and abroad. This timeline of Dr. Gray's postwar life, however, also brings to light the tragic loss of his wife and children. Furthermore, it shows how Gray's friendship with Whitman was significantly altered if not "entirely broken up" by Gray's personal tragedies as well as the geographical and professional distances between the two men in the aftermath of the Civil War.

Although Whitman and Gray would never re-establish the intimate friendship they shared in the pre-war years, they did manage at least one brief reunion when Gray was starting a family and studying medicine in New York. While visiting his family in Brooklyn in September 1867, Whitman wrote to his comrade and ardent defender William Douglas O'Connor about the encounter: "I have seen Fred. Gray, Nathaniel Bloom - the dear, good, affectionate young men - more kind, more affectionate than ever" (Shively, 150). However, these associates could not revive their former social circle, and Whitman continued to lament his general lack of contact with his "dear comrade Frederickus" (Corr, $1: 158$ ) as well as the dissolution of his friendships with other members of the Association. Upon returning to New York in 1870 to see the fifth edition of Leaves of Grass through the printing process, Whitman once again attempted to reconnect with his former drinking buddies. In a September 6, 1870, letter to Peter Doyle, his lover at the time, Whitman wrote that he was back to his old habit of loafing around the city: "I fall in with quite a good many of my acquaintances of years ago-the young fellows, (now not so young) - that I knew intimately here before the war-some are dead-\& some have got married" (Corr, 2:109). Whitman not only mourned the loss of former associates who died in battle, but he also seemed sad that many of the survivors had given up bachelorhood, settled down with their wives, and started families. If Gray was among the comrades that Whitman visited in 1870, the poet would have been sitting down to dinner with Fred Gray the Civil War veteran, father, and soon-to-be doctor. Gray was no longer a frequenter of bar-rooms nor was he the recently married, first-time father 
that reunited with Whitman in $1867 . .^{45}$ This time Gray's age would have been closer to thirty than twenty, his third child would have only just been born, and his life would have fit perfectly within Whitman's description of the Association's former bachelors, now comfortably established in homes of their own. Indeed, Whitman's latest reunion with these long lost associates-who, in 1870, were "not so young" or pumped full of beer-cellar bravado-almost certainly brought on the feelings of nostalgia he expressed in his letter to Doyle. But regardless of whether Gray and Whitman saw one another before the poet returned to Washington, Whitman eventually lost track of Gray for good, most likely after Gray set sail for Europe.

When Dr. John F. S. Gray returned to the United States after several years of living in Italy, France, and Switzerland, he went to New York but eventually made his way westward to California's shores. ${ }^{46}$ He married his second wife, Frances, on February 1, 1883. Two years later, in May 1885, the couple was registered as "new arrivals" at the Sanatorium (formerly Our Home on the Hillside), a Dansville, New York, health spa operated by Drs. James H. and Kate J. Jackson, who favored exercise, raw foods, and mineral spring baths over drug-based cures. ${ }^{47}$ Following their stay at the Sanatorium, Dr. Gray and his wife moved to El Cajon, San Diego County, California, where, in 1886, Dr. Gray was granted a license to practice medicine and surgery by the State of California. ${ }^{48}$ By 1890, he had been elected president of the Point Loma Lodge Theosophy Society, also in San Diego. However, Gray held the position mostly in name and spirit since his declining health and professional practice necessitated yet another move, this time to St. Clair Springs, Michigan, where he generally treated his own ailments in addition to continuing his medical research - pursuits that prevented him from taking any direct role in the California organization. ${ }^{49}$

Dr. Gray and his wife relocated to St. Clair Springs at the urging of William Sherwood Hopkins, a dear friend of Dr. Gray's, who had undertaken the development of two mineral springs as well as the construction of the Oakland Hotel and bath-house on the west bank of Michigan's St. Clair River. ${ }^{50}$ In an 1890 article in the Fournal of Balneology (the study of baths and bathing), which would also be printed as a twenty-three page pamphlet entitled Notes on the mineral waters of St. Clair Springs, Michigan: Their efficacy in the treatment of diseases, Dr. Gray explained that Hopkins invited him to "inspect, as a matter of medical interest and study, the mineral waters upon his [Hopkins's] property." The promise of the company of a friend "with whom he had been intimately associated," coupled with opportunities to renew his medical interest in therapeutic bathing and enjoy the health benefits of regular mineral baths, convinced Dr. Gray to travel to the Oakland 
Hotel and experience the waters of the "Salutaris" and the "St. Clair" springs for himself (Gray, 123-124). Shortly after his arrival, Dr. Gray joined the medical staff of the Oakland as a Consulting Physician, and he began bathing in the springs in addition to observing the treatment and dietary regimens of several other patients. He went on to extol the curative powers of the waters and even credited them with relieving symptoms related to his own kidney ailments in his article and pamphlet, which seem to have been his only publications (Gray, 127; CSP, 253). Yet, despite the benefits of approximately one year of therapeutic bathing at St. Clair Springs, Gray succumbed to the lung and kidney troubles that had impaired his health at least since his resignation from the army. He died on Monday, August 17, 1891, at the age of fifty-one, seven months before Whitman passed away; the cause of his death was Bright's Disease, a term that, in the nineteenth century, was frequently applied to a variety of kidney conditions. ${ }^{51}$

In 1904, nearly thirteen years after Dr. John F.S. Gray's death, his widow Frances Gray, then residing at No. 1641 Fifth Street in San Diego, filed a claim (House of Representatives Committee on Invalid Pensions, Bill S. 265) for an increase in the monthly military pension she had been receiving since her husband's death. ${ }^{52}$ Gray himself had never requested any of his pension funds but, at the time of her plea, Frances's only source of income was a pension check in the amount of $\$ 8$ per month. Seemingly without additional financial resources and having no children to assist her, Frances often took in boarders to support herself. After considering both Frances Gray's poverty and her husband's admirable record of service to his country, the House passed the bill thereby raising her pension to $\$ 20$ per month as of January 26 , $1904 .^{53}$ However, it is worth noting that despite awarding these funds to Frances, the Committee never officially conceded that Dr. John F. S. Gray's case of Bright's Disease resulted from his Civil War service, a belief that Dr. Gray held throughout his life.

It was the House Committee's report on Frances Gray's claim with which I began my own efforts to track down Dr. John F. S. "Fred" Gray, the young man with whom Whitman lost touch but clearly never forgot. Given that Gray spent at least the last five years of his life (1886-1891) in California and Michigan, and given that Whitman's own health was failing due to a series of paralytic strokes, it is unlikely that Whitman and Gray reunited during this period. But Whitman did read and preserve the volume of German prose that Gray had given him. On November 24, 1888, in his Mickle Street apartment in Camden, Whitman once again opened Hedge's Prose Writers of Germany and, on the first blank sheet he wrote, " $[\mathrm{H}]$ ave had this Vol. over twenty-five years \& read it off \& on many hours, days \& nights." ${ }^{4}$ Whitman's many returns to this book and the fact that he saved it all his life suggest that its famil- 
iar pages - several covered with personal memoranda-functioned as fond reminders of his meetings and late wanderings with Gray and the Association.

While Whitman kept Gray's going-away present, the two card photographs of the young soldier, and his memories of their "good old times" at Pfaff's close to his heart, Whitman's friendship with Gray and his ties to the other members of their social circle have yet to be fully explored by scholars. Fred Gray's status as a medical student, a soldier, and a link to (if not a part of) the Broadway medical community lends support to claims that Whitman often visited New York's beer cellars in the company of local doctors and the stage drivers and firemen they treated. This updated and clearer portrait of Fred Gray's life also raises new and important questions about Whitman's relationship to Theosophy (a movement in which Fred participated late in his life), Homeopathy (the form of medicine Fred's father practiced), and other medical developments both before and after the war. Taking up these questions will almost certainly lead to fresh conceptions of Whitman's role in the Fred Gray Association and a better understanding of how his participation in this group served as a long foreground for his attempts to nurse injured soldiers in Washington hospitals and his efforts to heal the national body with his postwar editions of Leaves of Grass.

The University of Iowa

\section{NOTES}

1 Reprinted in Charley Shively, ed., Drum Beats: Walt Whitman's Civil War Boy Lovers (San Francisco: Gay Sunshine Press, 1989), 147-149.

2 Walt Whitman: The Correspondence, ed. Edwin Haviland Miller (New York: New York University Press, 1961-1977), 1:158-160. Hereafter Corr.

3 The quotation refers to Whitman's brief reminisces about the group's "late wanderings" in his Letter to William D. O'Connor, September 11, 1864; Corr, 1:241. The other associates and potential members of the Fred Gray Association that Whitman mentions in this letter are "Perk," Ben Knower, Charles Kingsley, Charles Russell, and Charles Chauncey.

4 Ed Folsom and Kenneth M. Price, "Intimate Script and the New American Bible: 'Calamus' and the Making of the 1860 Leaves of Grass," Re-scripting Walt Whitman: An Introduction to His Life and Work (Malden, MA: Blackwell, 2005), 62.

5 Lehigh University's The Vault at Pfaff's (http://digital.lib.lehigh.edu/pfaffs/) is a web archive that provides access to biographical information as well bibliographies of texts by and about Pfaff's patrons during the late 1850s and early 1860 s, the years when Whitman frequented the beer cellar. See "The Fred Gray Association," The Vault at 
Pfaff's: An Archive of Art and Literature by New York City's Nineteenth-Century Bohemians, ed. Edward Whitley (http://digital.lib.lehigh.edu/pfaffs/people/groups/158/). See also Edward Whitley, "walt_whitman@pfaffs.bar: Bohemia on the World Wide Web,” Mickle Street Review 19-20 (http://micklestreet.rutgers.edu/).

\section{Draft Letter to Hugo Fritsch, August 7, 1863; Corr, 1:127.}

7 After receiving the Hedge volume on August 29, 1862, Whitman noted this date and Fred's instructions in the book. See Frederic Hedge, Prose Writers of Germany (Philadelphia: Carey and Hart, 1848), from the library of Walt Whitman; with his notes and memorabilia of a former owner, John F.S. Gray, Canaday Library, Bryn Mawr College. All references to Frederic Hedge's Prose Writers of Germany are to Whitman's notes on the early pages of his copy, which is currently housed in Special Collections at Bryn Mawr College. Whitman's notes are also reprinted in Walt Whitman: Complete Poetry \& Selected Prose and Letters, ed. Emory Holloway (London: The Nonesuch Press: 1967), 1099. Whitman's notes as well as a list of Bryn Mawr College's holdings of Whitman's books can also be found in Peter Van Egmond, "Bryn Mawr College Library Holdings of Whitman Books," Walt Whitman Review 20 (June 1974), 41-50.

8 Catalogue of the Sigma Phi with the Thesaurus, (Printed for the Society, Boston: T. R. Marvin \& Son, 1891), 252-253. Hereafter CSP.

9 Whitman would develop an interest in many of the writers included in Hedge's Prose Writers of German, culminating in the poet's notes for his "Sunday Evening Lectures" on Kant, Fichte, Schelling, and Hegel, notes that would eventually influence his published writings in the 1870 s and 1880 s, where Hegelian thought becomes increasingly important for him; see Gary Wihl, "The Manuscript of Walt Whitman's 'Sunday Evening Lectures," Walt Whitman Quarterly Review 18 (Winter 2001), 107-133. As Mark Bauerlein suggests, Whitman may well have not read more of Hegel than the summary and selections in the Hedge volume; see "Georg Wilhelm Friedrich Hegel," J. R. LeMaster and Donald D. Kummings, eds., Walt Whitman: An Encyclopedia (New York: Garland, 1998), 271-272.

10 Frederic Hedge, Prose Writers of German, from the library of Walt Whitman; Van Egmond, 45.

11 Charles van Ravenswaay, "August P. Brassart, An Associate of Daguerre," Image Fournal of Photography of the George Eastman House 3 (March 1954), 18.

12 Annual Report of the Adjutant-General of the State of New York for the Year 1899: Registers of the Twentieth, Twenty-first, Twenty-second, Twenty-third, Twenty-fourth, and Twenty-fifth Regiments of Infantry (Albany, NY: James B. Lyon, State Printer, 1900), 46. See also "Frances Gray," United States Congressional Serial Set, 58 ${ }^{\text {th }}$ Congress, 2d Session, Report No. 474 (Washington: United States Government Printing Office, 1904), 1-2.

13 Theodore Howard Genoways, "Whitman's Lost War: America's Poet During the Forgotten Years of 1860-1862," (Ph.D. Dissertation, University of Iowa, July 2007), 208. 
14 The War of the Rebellion: A Compilation of the Official Records of the Union and Confederate Armies, Series 1, Vol. 19, Part 1 (Washington: Government Printing Office, 1887), 401-403. Series I, 1-53; Series II, 1-8; Series III, 1-5; Series IV, 1-4 (1880-1901) of the Official Records volumes have been made available (and searchable) online at Cornell University Library's Making of America (MOA) project, a digital library of historical and primary sources covering the antebellum period through reconstruction (http://cdl.library.cornell.edu/moa/browse.monographs/waro.html). Hereafter Official Records.

15 Frederic Hedge, Prose Writers of German, From the library of Walt Whitman; Van Egmond 46.

16 Draft Letter to Hugo Fritsch, August 7, 1863; Corr, 1:126.

17 Edwin Miller notes that obituaries for John F. S. Gray appeared in the New York Herald and Tribune on August 19, 1891. See Corr, 1:81n.

18 See also Donald Yannella, “Fred Gray,” Walt Whitman: An Encyclopedia, 259.

19 Letter to Nathaniel Bloom and John F. S. Gray, March 19-20, 1863; Corr, 1:85.

20 Emory Holloway, Free and Lonesome Heart: The Secret of Walt Whitman (New York: Vantage Press, 1960), 119.

21 See also Roy Morris, The Better Angel: Walt Whitman in the Civil War (Oxford: Oxford University Press, 2001), 38-39. Morris contends that Whitman often drank and dined with the American Bohemians, physicians from New York Hospital, and the members of the Fred Gray Association while intentionally keeping the groups apart as "a function perhaps of his homosexual closeting" (38-39). But Fred Gray's status as the son of a New York physician, a medical student, and a soldier suggests that the connections between Whitman's Pfaffian social circles have yet to be fully understood. See also Christine Stansell, "Whitman at Pfaff's: Commercial Culture, Literary Life and New York Bohemia at Mid-Century," Walt Whitman Quarterly Review 10 (Winter 1993), 107-126. Stansell convincingly argues that Whitman's associates at Pfaff's have profoundly shaped his literary career.

22 Marcius Denison Raymond, Gray Genealogy: Being a Genealogical Record and History of the Descendants of Fohn Gray, of Beverly, Mass., and Also Including Sketches of Other Gray Families (Tarrytown, N.Y.: Higginson Book Co., 1887), 22, 136. John Frederick Schiller Gray is recorded as John F. S. Gray in Raymond and elsewhere, albeit less frequently, as John F. Sch. Gray, John Frederic Sch. Gray, and J. F. S. Gray. Although The Vault at Pfaff's lists 1834 as the birth date of John F. S. Gray, this volume first records his date of birth as July 1840, but amends it to August 12, 1840, as part of a series of corrections and addenda (136). Since the Frederic Hedge volume that Fred Gray gave Whitman had been a present to Fred from his own father on August 12,1856 , it makes sense that this date was his birthday and that the book was intended to mark the occasion. Raymond also lists (22) John F. S. Gray's siblings including two sisters, Elizabeth W. and Mary L. Gray, both of whom survived to adulthood and had families of their own. Deceased siblings of John F. S. Gray (children of Dr. John F. Gray and Elizabeth Hull-Gray) include John, Josephine, John 2d, Geraldine (aged 19), and Edward (age 16). 
23 John S. Haller, The History of American Homeopathy: The Academic Years, 18201935 (New York: Haworth Press, 2005), 41.

24 Dr. John Franklin Gray, The Early Annals of Homcepathy in New York: A Discourse Before the Homoeopathic Societies of New York and Brooklyn, on the $10^{\text {th }}$ of April, 1863, the Anniversary of the Birthday of Hahnemann (New York: Homœopathic Medical Society of the County of New York, 1863), 3.

25 John S. Haller, Kindly Medicine: Physio-medicalism in America, 1836-1911 (Kent, $\mathrm{OH}$ : Kent State University Press, 1997), 10; John S. Haller, The History of American Homeopathy, 41.

26 Haller, The History of American Homeopathy, 43. Dr. John F. Gray was also the attending physician at the end of Bryant's life. See Parke Godwin, The Life and Works of William Cullen Bryant: A Biography of William Cullen Bryant with Extracts from His Private Correspondence (New York: D. Appleton and Company, 1883), 2:405-406.

27 General Catalogue of the Non-Graduates of Williams College (Williamston, MA: Published by the College, 1910), 30; Catalogue of the Sigma Phi, E. P. V., (Syracuse, NY: C. W. Bardeen, Publisher, 1884), 100. This Catalogue of the Sigma Phi lists Gray's home address as 68 Madison Avenue, New York City.

28 Annual Report of the Adjutant-General of the State of New York for the Year 1899, 46; United States Congressional Serial Set: Report No. 474, 1.

29 Letter from Fred Gray to Walt Whitman, May 1, 1863; reprinted in Shively, 147-149.

30 "Report of Maj. Gen. William F. Smith, U.S. Army, commanding Sixth Army Corps," December 31, 1862. Official Records, Series 1, Vol. 21, 522-524.

31 United States Congressional Serial Set: Report No. 474, 1; General Orders of the War Department: Embracing the Years 1861, 1862, \& 1863, Adapted Especially for the Use of the Army and Navy of the United States, 2 Vols., (New York: Derby \& Miller, 1864), 2:2.

32 United States Congressional Serial Set: Report No. 474, 1; The United States Service Magazine, Volume I (New York: Charles B. Richardson, Broadway, 1864), 49.

33 Official Records, Series 1, Volume 34, Part III-Correspondence, etc., General Orders No. 192; 490.

34 Official Records, Series 1, Vol. 41, Part IV-Correspondence; 644.

35 Official Records, Series 1, Vol. 41, Part IV_Correspondence; 881.

36 Fournal of the Executive Proceedings of the Senate of the United States of America from December 5, 1864, to February 6, 1866, Inclusive, Vol. 14, Part I (Washington: Government Printing Office, 1887), 64; Francis B. Heitman, Historical Register and Dictionary of the United States Army From its Organization, September 29, 1789 to March 2, 1903, Vol. 1 (Washington: Government Printing Office, 1903), 472. 
38 John F. S. Gray's resignation from the military appears in Francis B. Heitman, Historical Register and Dictionary of the United States Army, from its Organization, September 29, 1789, to March 2, 1903, Volume 1 (Washington: Government Printing Office, 1903), 472. Marcius Raymond writes that John F. S. Gray married "Anna Howell" (22). Gray's wife is also called "Anna" in a biographical sketch of her son, Gerald Hull Gray. See "Gerald Hull Gray," Secretary's Report, Harvard College (Boston: Rockwell and Churchill Press, 1909), 85-86. However, her New York Times obituary records her as "Laura Howell, wife of John F. S. Gray, M.D"; therefore, "Laura" could be her first or her middle name. See "Died-Gray," New York Times (December 10, 1873), 5.

39 Catalogue of the Alumni, Officers, and Fellows, 1807-1880 (College of Physicians and Surgeons, Medical Department of Columbia College in the City of New York. New York: Bradstreet Press, 1880), 157; William S. Whitwell and William W. Kerr, eds. Pacific Medical and Surgical fournal and Western Lancelot (April 1886), 241.

40 "Gerald Hull Gray, Deputy Assistant District Attorney," The Brown Book: A Biographical Record of Public Officials of the City of New York for 1898-9, (New York: Martin B. Brown Company, 1899), 187.

41 Dr. Gray's academic pursuits and moves between cities suggest that he traveled to Europe alone; however, it remains uncertain whether his surviving children (Gerald, John, and Elizabeth) visited him while he was living and studying abroad.

42 General Catalogue of the Non-Graduates of Williams College 30; William S. Whitwell and William W. Kerr, eds. Pacific Medical and Surgical fournal and Western Lancelot (April 1886), 241; CSP, 252-253.

43 "Notices of Meetings: The Geneva Congress of Hygiene," The Sanitary Record and Fournal of Sanitary and Municipal Engineering (August 15, 1882), 85-86.

44 Adolphe Smith, "The Fourth International Congress of Hygiene," The Phrenological Fournal and Life Illustrated, A Repository of Science, Literature, and General Intelligence, 76.1 (January 1883), 40-45.

45 If Whitman saw Gray during this period, he did not record the details of the reunion in the Hedge volume.

46 J.F.S. Gray, M.D., “The Mineral Waters of St. Clair Springs, Mich.: Their Application to Diseased Conditions, Etc.," Fournal of Balneology, 4.4 (October 1890), 123-127. According to its cover, the fournal Of Balneology was a bi-monthly magazine that contained "information regarding Natural Mineral Springs, Health Resorts, Sanitariums, Etc.”

47 "Arrivals," The Laws of Life: A Family Health Fournal 28 (May 1885), 192. The Laws of Life was conducted by the faculty of the Sanatorium. 
48 United States Congressional Serial Set: Report No. 474, 2; Pacific Medical and Surgical fournal (April 1886), 241.

49 "Obituary," The Path: A Magazine Devoted to the Brotherhood of Humanity, Theosophy in American, and the Study of Occult Science, Philosophy, and Aryan Literature 6 (September 1891), 196.

50 "Publisher's Topics: The Oakland Hotel," The Cyclopedic Review of Current History (also known as The Quarterly Register of Current History) 2.6 (May 1892), iii.

51 United States Congressional Serial Set: Report No. 474, 2. There is some debate over whether Dr. John F. S. Gray died on August 17 or August 18, 1891. When referring to the House of Representatives Report, I will use the death date included therein. For an additional source that records August 17, 1891, as Gray's death date see: Bibliography of American Imprints to 1901: Compiled from the Data Bases of the American Antiquarian Society and the Research Libraries Group, Inc, v. 54 (New York, 1993), 186. Sources that record August 18, 1891, as Gray's death date include: Obituary: Dr. John F. S. Gray. The Path 6 (September 1891), 196. See also Obituary: Dr. John F. S. Gray, New York Times (August 19, 1891), 5.

52 United States Congressional Serial Set: Report No. 474, 1.

53 United States Congressional Serial Set: Report No. 474, 2.

54 Frederic Hedge, Prose Writers of Germany, from the library of Walt Whitman; Van Egmond, 45. 